\title{
TINJAUAN AWAL ASPEK TIPOLOGI DAN DATA INSKRIPSI BATU NISAN DI HOLLANDISCHE KERK BANDA NEIRA
}

\section{EARLY REVIEW OF TYPOLOGY ASPECT AND INSCRIPTIONS ASPECT OF TOMBSTONE IN HOLLANDISCHE KERK BANDA NEIRA}

\author{
Syahruddin Mansyur \\ Balai Arkeologi Maluku-Indonesia \\ Jln. Namalatu-Latuhalat, Nusaniwe, Ambon \\ e-mail: hitam_putih07@yahoo.com

\begin{abstract}
Abstrak
Kepulauan Banda dikenal sebagai wilayah yang memiliki pengaruh kolonial yang kuat. Salah satu tinggalan arkeologi yang banyak ditemui di wilayah ini adalah batu nisan. Sebagai salah satu budaya materi, batu nisan memiliki beragam informasi yang terdapat pada batu nisan itu sendiri mulai dari bentuk, bahan, dan ragam hias. Penelitian ini merupakan tinjauan awal untuk mengetahui tipologi dan beragam informasi yang dapat diungkap dari inskripsi yang termuat pada batu nisan. Melalui tahapan penelitian arkeologi dengan melakukan analisis terhadap keragaman jenis artefak dan analisis terhadap data inskripsi, penelitian ini mengungkap bahwa tipologi batu nisan memiliki kekayaan ragam hias berupa lambang heraldik, iluminasi, dan inskripsi. Aspek lain pada data inskripsi adalah informasi tentang orang-orang yang dimakamkan memiliki status sosial tinggi, di antaranya; para pejabat pemerintahan, pejabat militer, pejabat perdagangan, pejabat keagamaan, para perkenier, beserta para keluarganya. Aspek lain yang berhasil diungkap bahwa kehidupan sosial masyarakat Eropa saat itu menganggap bahwa batu nisan adalah salah satu simbol kemewahan.
\end{abstract}

Kata kunci: batu nisan, Banda Neira, kolonial.

\section{Abstract}

Banda Islands are known as the region that has a strong colonial influence. One of the archaeological remains found in the region is the tombstone. As one of the material culture, the tombstone has a variety of information contained on a tombstone itself from the shape, material, and ornaments. This study is a preliminary review to determine the typology and variety of information that can be revealed from inscriptions contained in the tombstone. Through the stages of archaeological research by analysing the diversity of artefacts and analysis inscriptions data, this study revealed that the typology of the tombstone has a wealth of ornamentation in the form of heraldic emblem, illumination, and inscriptions. Another aspect from the inscription data is information about people who are buried has a high social status. They are from government officials, military officials, trade officials, religious officials, the perkenier (landlord), along with his family. Another aspect that can be revealed is the social life of Europe in that time considered that the tombstone is one of the symbols of luxury.

Keywords: tombstone, Banda Neira, colonial.

\section{A. PENDAHULUAN}

Kepulauan Banda dikenal sebagai wilayah yang memiliki pengaruh kolonial Eropa (khususnya Belanda) yang sangat kuat. Persentuhan awal bangsa Eropa dengan Kepulauan Banda tidak lepas dari sejarah wilayah ini sebagai penghasil utama salah satu jenis komoditi rempahrempah, yaitu buah pala. Berawal dari kontak perdagangan dengan penduduk pribumi, akhirnya bangsa Eropa khususnya Belanda menempuh kebijakan untuk 
mengelola sendiri produksi pala. Kebijakan yang ditempuh saat itu adalah sistem perken dengan menyerahkan pengelolaan perkebunan pala kepada orang-orang Eropa. Lahan-lahan perkebunan pala dibagi sebanyak 34 perk (kompleks perkebunan pala) yang tersebar di Kepulauan Banda, yaitu 3 di Pulau Neira, 6 di Pulau Ay, dan 24 di Pulau Lonthor (Wall, 1928). Rentang historis pengelolaan produksi pala oleh Belanda inilah yang kemudian meninggalkan jejak budaya materi berupa bangunan-bangunan dengan arsitektur kolonial di Kepulauan Banda. Selain perk yang terdiri atas lahan perkebunan, rumah pengasapan pala, rumah tinggal pekerja dan rumah tinggal pengawas pekerja pala, tinggalan lain yang masih dapat disaksikan di Kepulauan Banda adalah benteng-benteng pertahanan, kantor pemerintahan, bangunan keagamaan, rumah tinggal, dan makam-makam Eropa.

Terkait upaya mengungkap aspek sejarah budaya di Kepulauan Banda, berbagai penelitian arkeologi telah dilakukan. Hingga saat ini, Balai Arkeologi Ambon telah melakukan penelitian yang berhasil menjaring data terkait peninggalan arkeologi masa kolonial di Banda Neira. Penelitian lain yang dilakukan adalah penelitian tahun 2009, untuk mengidentifikasi persepsi masyarakat tentang pengelolaan benda cagar budaya yang ada di Banda Neira (Tim Penelitian, 2009). Sementara itu, Pusat Penelitian dan Pengembangan Arkeologi Nasional melakukan serangkaian penelitian eksploratif untuk mengidentifikasi tinggalan arkeologi yang ada di wilayah Kepulauan Banda (Tim Penelitian, 2010). Penelitian tersebut kemudian ditindaklanjuti dengan melakukan metode ekskavasi di salah satu bekas lokasi perk yang ada di Pulau Banda (Tim Penelitian, 2012). Sementara itu, Peter Lape peneliti dari Amerika Serikat, melakukan serangkaian penelitian sejak tahun 1997 hingga tahun 2007, yang bertujuan untuk merekonstruksi kembali pola-pola pemu- kiman dan jaringan perdagangan pada masa pra-kolonial dan awal kolonial di Kepulauan Banda (Alwi, 2005: 18-19).

Sementara itu, penelitian yang bersifat khusus belum pernah dilakukan, misalnya melakukan kajian terhadap salah satu bentuk tinggalan arkeologi yang ada di Kepulauan Banda. Hasil penelitian Pusat Penelitian dan Pengembangan Arkeologi Nasional pada tahun 2010, terdapat beberapa tempat yang merupakan lokasi penguburan bagi warga Eropa di Kepulauan Banda. Tempat-tempat tersebut, di antaranya: kerkhoflaan (kompleks pemakaman warga Kristiani pada masa Belanda) yang ada di Desa Merdeka (Neira), juga terdapat di kompleks Perk Mangkubatu yang ada di Desa Rajawali, lokasi gereja tua di Kota Neira, dan di lokasi bekas gereja tua yang ada di Pulau Ay (Tim Penelitian, 2010).

Salah satu tinggalan arkeologi yang menarik untuk dikaji adalah makam Eropa yang ada di Kepulauan Banda. Makammakam Eropa pada umumnya memiliki batu nisan yang memuat lambang dan inskripsi. Terdapat dua alasan tentang pentingnya kajian terhadap batu nisan Eropa, sebagaimana dikemukakan oleh Suratminto (2008), yaitu; pertama, lambang verbal dalam bentuk inskripsi pada batu nisan yang menceritakan nama dan biografi singkat orang yang dimakamkan; dan kedua, makna dan pesan yang ada di balik lambang dan inskripsi serta hubungan lambang dengan orang atau keluarga yang dimakamkan. Tujuan penelitian terhadap makam Eropa itu sendiri adalah berupaya merekonstruksi struktur sosial dan budaya komunitas warga Eropa (Suratminto, 2008: 8). Dalam penelitian arkeologi, kajian terhadap batu nisan umumnya lebih menitikberatkan pada nisan-nisan Islam dengan berbagai tipe yang tersebar di seluruh Nusantara. Sementara, kajian terhadap batu nisan Eropa tidak banyak mendapat perhatian. Penelitian-penelitian arkeologi umumnya memandang tinggalan batu nisan atau (kompleks) makam Eropa 
dalam konteks yang lebih makro yaitu sebagai bagian dari elemen pembentuk pola pemukiman sebuah kawasan (Abrianto, 2010: 157; Inagurasi, 2014: 55; dan Koestoro, dkk, 2013: 74). Penelitianpenelitian dalam konteks yang lebih mikro, sebagaimana dilakukan oleh Rosaeny Handayani pada tahun 2009 dituangkan dalam skripsi berjudul "Bentuk-bentuk Nisan Eropa di Museum Taman Prasasti Jakarta”. Demikian halnya penelitian yang dilakukan oleh Lilie Suratminto pada tahun 2008 yang dituangkan dalam buku berjudul "Makna Sosio-Historis Batu Nisan VOC di Batavia".

Dengan demikian, beberapa alasan pemilihan topik pada tulisan ini, di antaranya; pertama, Kepulauan Banda merupakan wilayah yang memiliki pengaruh kolonial yang kuat, hal ini tampak pada berbagai bentuk tinggalan arkeologi yang ada di wilayah tersebut, salah satunya adalah batu nisan yang terdapat pada makam-makam Eropa; kedua, riwayat penelitian arkeologi yang dilakukan di wilayah ini masih bersifat umum dan eksploratif; ketiga, penelitianpenelitian arkeologi di Indonesia masih memandang batu nisan Eropa dalam konteks yang lebih makro; keempat, penelitian batu nisan Eropa yang bersifat mikro masih terbatas pada wilayah tertentu di Indonesia, sebagaimana yang telah dilakukan terhadap batu nisan Eropa yang ada di Museum Taman Prasasti di Jakarta.

Berdasarkan uraian sebelumnya, tampak bahwa penelitian yang bertujuan untuk mengkaji secara khusus salah satu bentuk tinggalan arkeologi belum pernah dilakukan di lokasi penelitian. Di sisi lain makam Eropa atau batu nisan Eropa merupakan tinggalan arkeologi yang cukup dominan di wilayah ini. Selain itu, penelitian-penelitian yang bersifat eksploratif yang dilakukan sebelumnya berhasil mengidentifikasi nisan-nisan Eropa yang memiliki tipe dan ragam hias yang bervariasi. Di sisi lain, kajian terhadap batu nisan Eropa dianggap penting karena dapat mengungkap berbagai aspek terkait upaya rekonstruksi struktur sosial dan komunitas warga Eropa. Dengan demikian, permasalahan yang dikaji difokuskan pada aspek tipologi batu nisan di lokasi penelitian dan aspek-aspek sosial yang dapat diungkap dari data inskripsi batu nisan.

Tulisan ini merupakan tinjauan awal terhadap tipologi dan aspek sosial batu nisan Eropa di Kepulauan Banda. Oleh karena itu, tulisan ini memiliki keterbatasan khususnya dalam mengungkap aspek sosio-historis. Lilie Suratminto (2008), dalam upaya mengungkap makna di balik batu nisan Eropa di Jakarta melakukan serangkaian analisis dan interpretasi dengan menggunakan pendekatan semiotik. Analisis semiotik mikro hingga analisis semiotik makro dilakukan terhadap data ikonis berupa lambang heraldik dan data teks berupa inskripsi pada batu nisan (Suratminto, 2008: 67-144). Sebagai tinjauan awal terhadap aspek tipologi dan aspek sosial, metode analisis yang digunakan dalam tulisan ini terbatas pada analisis keragaman jenis artefak dan analisis terhadap data inskripsi pada batu nisan.

\section{B. METODE PENELITIAN}

Penelitian ini bersifat deskriptif dengan mengikuti tahapan penelitian arkeologi, meliputi tahap survei, deskripsi dan eksplanasi (Deetz, 1967: 8). Survei dalam penjaringan dan perekaman data dilakukan dengan teknik meliputi observasi kepustakaan dan lapangan. Observasi kepustakaan yaitu mengumpulkan sebanyak mungkin data tentang deskripsi lokasi penelitian, latar belakang sejarah, dan halhal yang berkaitan dengan lokasi penelitian. Sementara observasi lapangan meliputi deskripsi verbal. Deskripsi verbal difokuskan pada pencatatan tentang inskripsi yang terdapat pada batu nisan yang ditemui di lokasi penelitian. Deskripsi piktorial (pemotretan dan penggambaran).

Tahap selanjutnya adalah tahap analisis data untuk mengidentifikasi bentuk dan tipe batu nisan yang ditemukan pada 
saat penelitian, di antaranya: keanekaragaman jenis artefak dari segi bentuk, stilistik, teknologi dan kronologi. Analisis juga dilakukan untuk memilah dan mengelompokkan berbagai jenis bentuk dan tipe batu nisan yang ditemui di lokasi penelitian. Analisis morfologi dilakukan dengan mengamati bentuk umum batu nisan dan ragam hiasnya. Analisis teknologi yaitu mengamati variabel-variabel yang meliputi bahan dan teknik pembuatan /konstruksi. Analisis stilistik yaitu mengamati ragam hias, baik berupa ragam hias arsitektural maupun dekoratif (Anonim, 2008: 98). Pada tahap ini juga dilakukan pemilahan dan pengelompokan berdasarkan pada keterangan-keterangan yang termuat pada inskripsi setiap batu nisan yang ada di lokasi penelitian. Keteranganketerangan yang dimuat pada inskripsi batu nisan umumnya adalah nama tokoh; kota, tanggal lahir; kota, tanggal meninggal; usia; jabatan; dan keterangan lainnya.

\section{HASIL DAN BAHASAN}

\section{Tipologi Batu Nisan Hollandische Kerk Banda Neira}

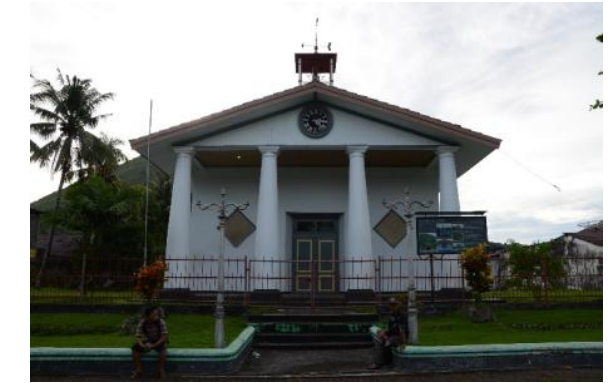

Gambar 1. Hollandische Kerk di Kepulauan Banda, Provinsi Maluku

Sumber: Balai Arkeologi Maluku, 2013.

Tinggalan arkeologi berupa makammakam Eropa tersebar di beberapa lokasi di Kepulauan Banda, di antaranya: di Kota Neira, yaitu: Hollandische Kerk atau Gereja Tua Neira, Istana Mini Banda, Kerkhoflaan (kompleks pemakaman bagi warga Kristiani pada masa Belanda) Desa Rajawali, dan Perk Lautaka; di Pulau Lonthor, yaitu: Perk Takarmoro, Perk Lautang, Perk Raning, dan Perk Walang Besar; serta di Pulau Ay, yaitu: lokasi
Gereja Tua Ay (Tim Penelitian, 2010: 4579). Tipologi makam-makam yang terdapat di Kepulauan Banda sebagian besar berupa batu nisan dengan inskripsi dan beberapa di antaranya dilengkapi dengan jirat. Makam yang memiliki jirat dan batu nisan dengan inskripsi terdapat di sekitar lokasi perk, baik di Pulau Ay maupun di Pulau Lonthor.

Selain bentuk-bentuk umum makam dan nisan, beberapa di antaranya juga memiliki tambahan bentuk yang bervariasi. Seperti yang tampak pada makam yang ada di lokasi Perk Takarmoro (Pulau Lonthor) yang memiliki dua nisan dengan kemuncak berbentuk gelombang dan pada bagian tengah terdapat jirat menyerupai bentuk keranda. Adapun kedua nisan pada makam ini terdapat hiasan dengan motif timbul dan inskripsi. Bentuk lain yang ada di Desa Lonthor adalah nisan yang dilengkapi dengan pedestal atau fondasi yang berfungsi sebagai penopang. Terdapat juga makam dengan kemuncak berbentuk kerucut.

Lokasi Hollandische Kerk di Kota Neira terdapat dua kelompok makam atau batu nisan, yaitu makam yang terdapat di halaman belakang dan samping gereja, serta batu nisan yang terdapat di lantai bangunan gereja. Makam yang terdapat di halaman gereja memiliki bentuk yang bervariasi yaitu makam dengan posisi horizontal serta makam dengan posisi tegak atau vertikal, dan keseluruhannya berjumlah lima makam. Makam-makam yang berada di halaman gereja ini pada umumnya tidak memiliki inskripsi, Informasi yang diperoleh dari pengurus gereja menyebutkan bahwa tokoh yang dimakamkan adalah para pendahulu pengurus gereja, baik pada masa kolonial maupun masa kemerdekaan. Adapun batu nisan yang terdapat di lantai bangunan gereja diletakkan dengan posisi berbaring. Batu nisan ini disusun di bagian teras depan, bagian dalam (ruang jemaat dan ruang pastoran), serta bagian teras belakang. 


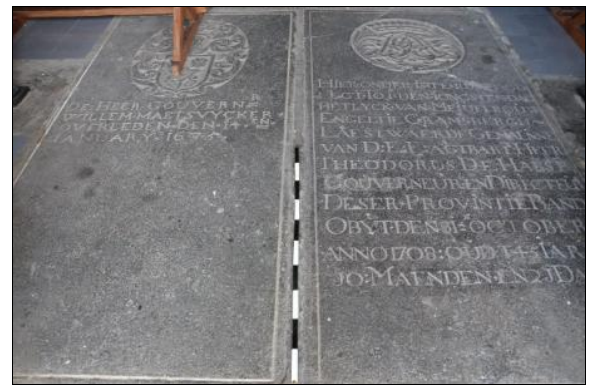

Gambar 2. Detail batu nisan pada lantai bangunan Hollandische Kerk di Kota Neira. Sumber: Balai Arkeologi Maluku, 2013.

Hollandische Kerk dibangun sekitar tahun 1600-an. Akibat gempa bumi yang dahsyat, gereja ini mengalami kehancuran dan dibangun kembali pada tahun 1852 , sebagaimana yang ada sekarang ini. Versi lain menyebutkan, bahwa gereja tua tersebut dibangun pada tanggal 20 April 1873, peresmian penggunaannya pada tanggal 23 Mei 1875 oleh dua orang penginjil yakni Lantzius dan John Hoeke. Selanjutnya gedung ini dibangun di atas 30 kuburan serdadu Belanda yang gugur dalam perang untuk menaklukkan Banda. Pada lantai gereja terlihat ada 30 buah batu nisan dari 30 orang serdadu Belanda, lengkap dengan identitasnya (Tim Penelitian, 2010: 45).

Sementara itu, penelitian yang dilakukan oleh Balai Arkeologi pada tahun 2013, mengidentifikasi jumlah batu nisan yang terdapat di lantai bangunan gereja, yaitu 27 nisan kubur dengan rincian sebagai berikut: 2 nisan kubur di teras depan, 24 nisan kubur di dalam ruang bangunan, dan 1 nisan kubur di teras belakang. Kondisi keseluruhan nisan kubur dan makam-makam yang ada di lokasi ini terawat cukup baik setelah gereja ini direnovasi dan difungsikan kembali pasca kerusuhan tahun 1999. Meski demikian, beberapa inskripsi yang terdapat pada nisan kubur dan makam tidak terbaca dengan baik karena nisan kubur telah mengalami keausan. Selain itu, terdapat batu nisan yang tidak teridentifikasi baik bentuk maupun inskripsinya karena keterbatasan pengamatan di lokasi penelitian yaitu MGTN 23 dan MGTN 24 (Tim Penelitian, 2013).

Tradisi pemakaman komunitas Kristen Kolonial telah berlangsung sejak awal kedatangan mereka di Nusantara. Pemakaman Kristen Kolonial di Batavia misalnya telah berlangsung sekitar abad ke-17 sampai akhir abad ke-18 berada di sekitar areal gereja, sehingga gereja tidak hanya dijadikan sebagai tempat peribadatan tetapi juga dijadikan sebagai tempat pemakaman, misalnya Gereja $D e$ Nieuw Hollandsche Kerk (Museum Wayang) dan Gereja Portugis atau Gereja Sion (Handayani, 2009: 14). Khusus batu nisan yang menjadi data penelitian ini berada di lantai bangunan gereja Hollandische Kerk. Secara umum, batu nisan yang ada di lantai bangunan masingmasing berbentuk persegi panjang. Posisi batu nisan disusun dengan rapi hingga membentuk konfigurasi atau bentuk tanda salib. Susunan batu nisan diletakkan saling berdampingan kiri dan kanan, mulai dari pintu masuk gereja hingga bagian mimbar gereja. Jumlah masing-masing batu nisan (dua batu nisan) yang disusun saling berdampingan adalah 10 baris mulai dari pintu masuk hingga bagian mimbar. Sementara itu, pada baris keenam terdapat tambahan masing-masing dua pada sisi kiri dan dua pada sisi kanan, sehingga pada baris ini terdapat enam batu nisan kubur yang disusun saling berdampingan dengan jumlah keseluruhan adalah 24 batu nisan.

Pengelompokan terhadap batu nisan yang ada di lokasi penelitian menggunakan pengkodean dengan akronim MGTN atau Makam Gereja Tua Naira. Sistem pengkodean ini berurut dari MGTN 1 sampai dengan MGTN 27 yang didasarkan pada deretan atau susunan makam yang ada di Kompleks Gereja Tua Naira (Hollandische Kerk) yaitu dari teras bagian depan, ruang jemaat, hingga teras bagian belakang bangunan gereja (lihat gambar 3). 


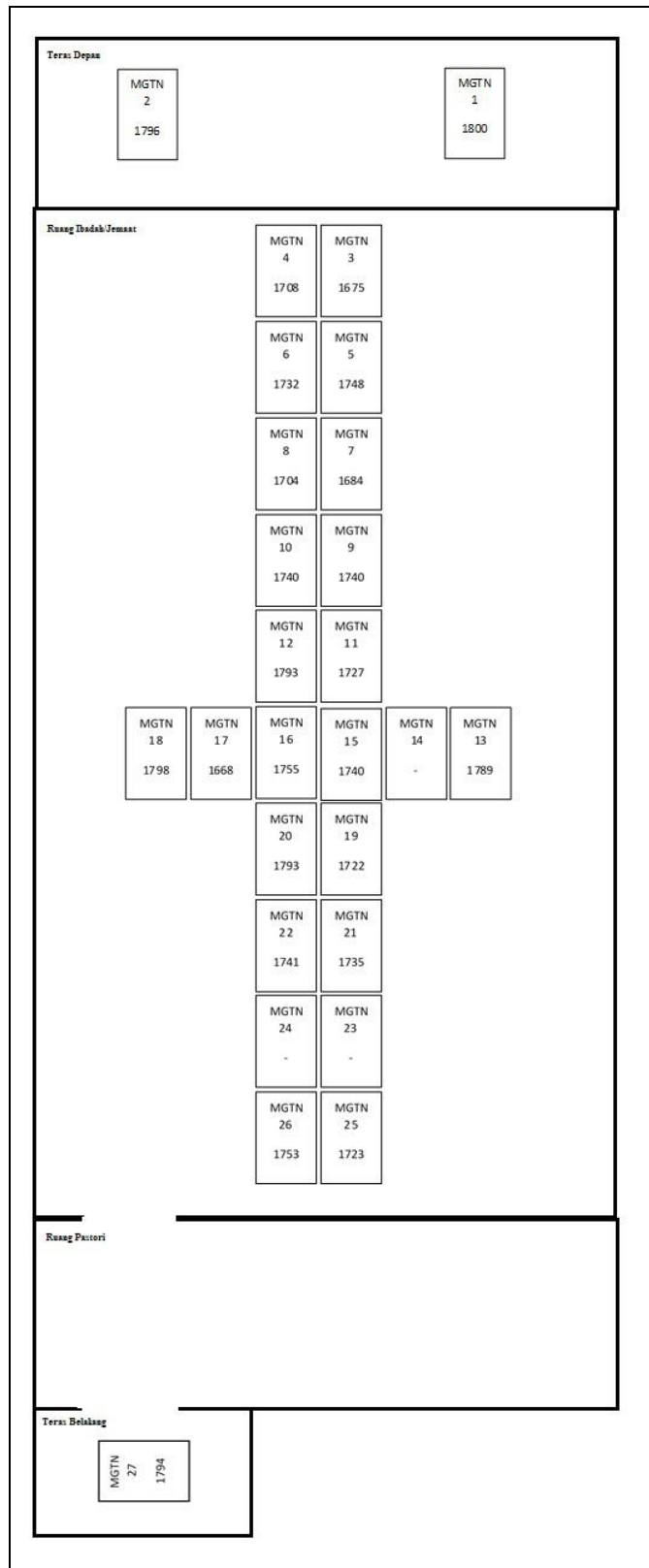

Gambar 3. Sketsa Denah Keletakan Batu Nisan (Kode nisan dan angka tahun berdasarkan inskripsi)

Sumber: Balai Arkeologi Maluku, 2013.

Batu nisan yang berada di lantai bangunan gereja, terbagi atas 3 bagian yaitu: hiasan tepi batu nisan (iluminasi), lambang heraldik atau ikonis (data nonverbal), dan inskripsi atau teks (data verbal). Dari keseluruhan batu nisan tersebut, masing-masing memiliki variasi bagian batu nisan, di antaranya; batu nisan yang memiliki ketiga kelengkapan bagian tersebut, serta batu nisan yang hanya memiliki dua atau satu kelengkapan bagian (lebih lengkap lihat tabel 1).

Bagian stilistik (heraldik dan inskripsi) pada batu nisan berada pada posisi yang bervariasi. Beberapa batu nisan menempatkan kelengkapan stilistik memenuhi keseluruhan badan batu nisan, namun ada juga yang hanya menempatkan pada bagian atas atau pada bagian bawah. Hal ini dipengaruhi oleh panjang atau pendeknya inskripsi yang tertera pada batu nisan. Demikian halnya posisi keletakan heraldik juga berada pada posisi yang bervariasi. Dari keseluruhan batu nisan terdapat 21 batu nisan yang memiliki lambang heraldik, dan 4 di antaranya tidak memiliki lambang heraldik. Sementara itu, dari 21 jumlah batu nisan yang memiliki lambang heraldik, 19 di antaranya berada pada bagian atas batu nisan, dan 2 di antaranya berada di tengah-tengah batu nisan.

Tabel 1. Kelengkapan Stilistik Batu Nisan di Hollandische Kerk.

\begin{tabular}{lcl}
\hline No. & Kode & $\begin{array}{l}\text { Kelengkapan Stilistik Batu } \\
\text { Nisan }\end{array}$ \\
\hline 1. & MGTN 1 & $\begin{array}{l}\text { Heraldik, Iluminasi, dan } \\
\text { Inskripsi }\end{array}$ \\
\hline 2. & MGTN 2 & Heraldik dan Inskripsi \\
\hline 3. & MGTN 3 & Heraldik dan Inskripsi \\
\hline 4. & MGTN 4 & Heraldik dan Inskripsi \\
\hline 5. & MGTN 5 & Inskripsi \\
\hline 6. & MGTN 6 & Heraldik dan Inskripsi \\
\hline 7. & MGTN 7 & Heraldik dan Inskripsi \\
\hline 8. & MGTN 8 & Heraldik dan Inskripsi \\
\hline 9. & MGTN 9 & $\begin{array}{l}\text { Heraldik, Iluminasi, dan } \\
\text { Inkripsi }\end{array}$ \\
\hline 10. & MGTN & $\begin{array}{l}\text { Heraldik, Iluminasi, dan } \\
\text { Inskripsi }\end{array}$ \\
\hline 11. & MGTN & $\begin{array}{l}\text { Heraldik, Iluminasi, dan } \\
\text { Inkripsi }\end{array}$ \\
\hline 12. & MGTN & Heraldik dan Inskripsi \\
& 12 & \\
\hline 13. & MGTN & Heraldik dan Inskripsi \\
& 13 & \\
\hline 14. & MGTN & Heraldik, Iluminasi, dan \\
& 14 & Inskripsi \\
\hline 15. & MGTN & Iluminasi dan Inskripsi \\
\hline 16. & MGTN & Inskripsi \\
\hline
\end{tabular}




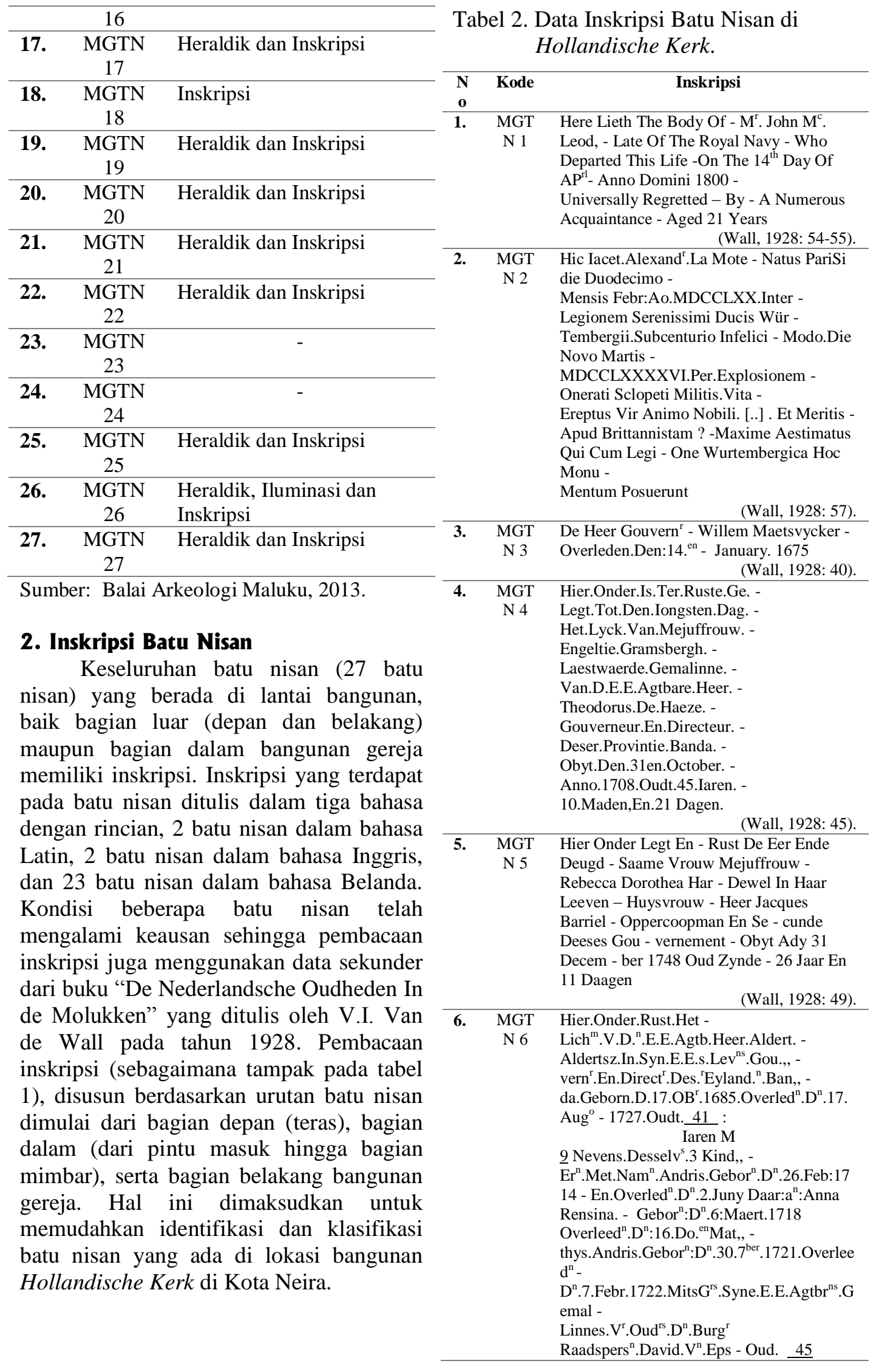




\begin{tabular}{|c|c|c|c|c|c|}
\hline & & 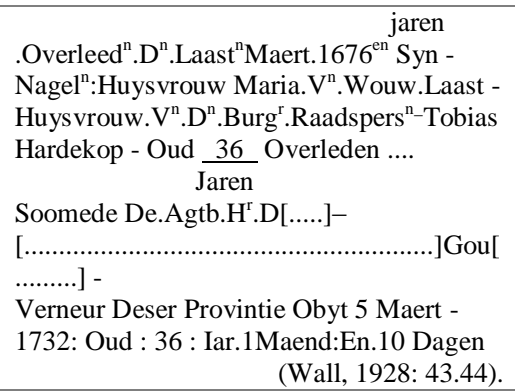 & 13 & $\begin{array}{l}\text { MGT } \\
\text { N } 13\end{array}$ & $\begin{array}{l}\text { Hier Onder Rusten Twee - Gebroeders - } \\
\text { Adrians. Petrus Scravesande - Gebooren Te } \\
\text { BandaNeira Den 16:November - A.1778 } \\
\text { En Overleden Den 7:Junny A.1789:In - } \\
\text { Den Ouderdom Van 10:Jaren 6:Maanden } \\
22 \text { Dag }^{n} \text {. - En - Cornelis Marianus Ju - } \\
\text { Docus Groeneveld Scra - } \\
\text { Vesande:Gebooren Te Banda P. - } \\
\text { Ay Den 9:October A.1784:En Over - Leden } \\
\text { Den 18 Juny A.1789: In Den - Ouderdom } \\
\text { Van } 4 \text { Jaren 8:Mann . En 9:Dagn. } \\
\text { (Wall, 1928: 57-58). }\end{array}$ \\
\hline 7. & $\begin{array}{l}\text { MGT } \\
\text { N } 7\end{array}$ & $\begin{array}{l}\text { Hier Leyt Begraven Maria Melgertssen - } \\
\text { Van.Haarlem.Geboren.A }{ }^{\mathrm{o}} .1624 . \text { Den - } \\
7^{\mathrm{e}} \text {.Mey.En.Overleden.Den.19 } 9^{\mathrm{e}} \text { Juny } 1684 \text { - } \\
\text { Laast.Geweest.Huisvrovwe Van Den - } \\
\text { Manhaften Jan Jacobse Heysselberg - } \\
\text { Cap }{ }^{\mathrm{n}} \text {.Militair.In.Dienst.Der.E. }{ }^{\mathrm{e}} \text { Comp. - } \\
\text { In Indie Gekomen In 't Jaar .29. } \\
\\
\text { Hier Leyt Begraven. - Den Eersamen Iacob } \\
\text { - Heysselbergh In Syn Le -Ven Corporael } \\
\text { In Dienst - Der:E } E^{\mathrm{e}} \text {.Comp. }{ }^{\mathrm{e}} \text { Overleden : - } \\
\text { Den } 21 \text { :October } 1683 \text { - } \\
\text { In Den Ouderdom Van - } 23 \text { Iaren } 3 \\
\text { Maenden En } 9 \text { - Dagen. }\end{array}$ & 14 & $\begin{array}{l}\text { MGT } \\
\text { N } 14\end{array}$ & $\begin{array}{l}\text { O, God: Den Hemel. Schenkenberg - Zyn } \\
\text { Siel, Wiens.Lichaam.Hier. - Begraven, } \\
\text { Wiens.Leven. Levens - Onder.Hiel. God: } \\
\text { Wild.Ons.Onder. - Schragen.Wand. } \\
\text { Al.Ons.Rust.En. - } \\
\text { Onse.Hoop.Is,Door.Zyn.Dood. - } \\
\text { Verdwenen, Het.Korten.Van. Zyn. - } \\
\text { Levensloop, Heeft.Veele. - } \\
\text { Reets.Doen.weenen, Maart.Dat. - Gy.Niet. } \\
\text { Weend.Eewiglyck.Laad. - } \\
\text { Hy.U.Voorbeeld.Weesen, Doet. - } \\
\text { Als.Hy.Deed.In.T. Wereltsryck. - } \\
\text { Gy.Sult.Ook.Zyn.Gepreesen } \\
\quad \text { (Wall, 1928: 40). }\end{array}$ \\
\hline \multirow[t]{2}{*}{8.} & \multirow[t]{2}{*}{$\begin{array}{l}\text { MGT } \\
\text { N } 8\end{array}$} & $\begin{array}{l}\text { (Wall, 1928: 50). } \\
\text { Hier Onder - Legt Begraven Het Lighaam - } \\
\text { Van Den E.E.Achtbare Heer - } \\
\text { Cornelis Stull In Zyn Leven - Gouverneur } \\
\text { En Directeur Deser - Provintie Banda } \\
\text { Overleden Op - Den 6 October Ao } 1704 \text { In }\end{array}$ & 15 & $\begin{array}{l}\text { MGT } \\
\text { N } 15\end{array}$ & $\begin{array}{l}\text { Hier Onder - Rust Het Leijck van - } \\
\text { Salomon Jacobsz Gebooren - } \\
\text { Tot Batavia den } 17 \text { Avgvsts - Ao.1677 } \\
\text { Overleden Alhier - Den } 5 \text { ten Septber Ao. } \\
1740 \text { - Zijnde Out } 73 \text { Jaaer En - 18 Daegen } \\
\qquad \text { (Wall, 1928: 58). }\end{array}$ \\
\hline & & 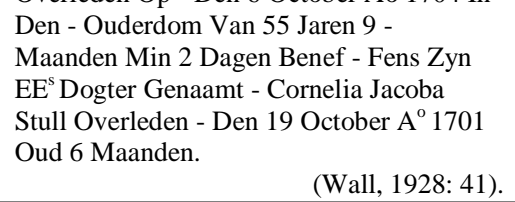 & \multirow[t]{3}{*}{16} & $\begin{array}{l}\text { MGT } \\
\text { N } 16\end{array}$ & $\begin{array}{l}\text { Hier Onder Rust Johan - nes van Surker, In } \\
\text { Zyn Le - Ven Burger en Perq' - Tot Rhanen } \\
\text { Obit } 12 \text { January - A } 1697 \text { Oud } 38 \text { jaar } 10 \\
\text { Maanden En - } 7 \text { Dagen Nevens Twe Zoons } \\
\text { Van Den - Winkelier In Dienst Der } \\
\text { E.Compag - Nie Floris Versteegh, Als Een }\end{array}$ \\
\hline 9. & $\begin{array}{l}\text { MGT } \\
\text { N } 9\end{array}$ & $\begin{array}{l}\text { Hier Onder Leggen Begraven - Nicalaus } \\
\text { Nicolai - In Leven Gouverneur En - } \\
\text { Directeur Op Banda - Overleden Den } 28 \\
\text { Maert } 1740 \text { - Oud } 44 \text { Jaren } 9 \text { Maanden En } \\
9 \text { Maenden - En } 24 \text { Dagen } \\
\text { (Wall, 1928: 42). }\end{array}$ & & & $\begin{array}{l}\text { - Nieuw Gebooren den } 16 \text { April } 1744 \text { - En } \\
\text { Nicolaas Obit Den } 18 \text { December - } 1748 \text { T } \\
\text { Laatste Oud } 3 \text { Maanden - En } 5 \text { Dagen. - } \\
\text { Hier Onder Leyt Ter Rusten - Pietronella } \\
\text { Van Surker - Huysvrouw Van Den } \\
\text { Titl.Luytent }{ }^{\text {nt }} \text { En Werfmeester - Hans }\end{array}$ \\
\hline \multirow[t]{3}{*}{10} & \multirow[t]{3}{*}{$\begin{array}{l}\text { MGT } \\
\text { N } 10\end{array}$} & $\begin{array}{l}\text { Hier Onder Rust Lighaam - Van Den } \\
\text { Eerwaarden Heer - Samuel Maesius. } \\
\text { Gewesen. - Bedienaar Des.Heiligen Evan - } \\
\text { gelium In De Christelyke Ge - } \\
\text { Meente Alhier Op Neira Ont - slapen Den }\end{array}$ & & & $\begin{array}{l}\text { George Hin[....] - Gebooren Den } 26 \text { August } \\
\text { Ao. } 1738 \text { - Getrouwd Den } 3 \text { August Ao. } \\
1755 \text { - En Overleeden Den } 3 \text { October } 1755 \\
\text { - Oud } 18 \text { Jaaren } 1 \text { Maend en } 7 \text { Daagen } \\
\text { (Wall, 1928: 53). }\end{array}$ \\
\hline & & $\begin{array}{l}19 \text { May A }{ }^{\circ} .1740 \text { In Den - Ouderdom Van } \\
32 \text { Iaar } 9 \text { Maen - den } 19 \text { Dagen.Mitsgaders } \\
\text { Het - Gebeente Van Desselfs Broe - } \\
\text { der Iohan.Philips Maesius, - Zynde } \\
\text { Geweest Adsistent In - Dienst Der } \\
\text { E.Comp.Overleden - Den } 17 \text { February A }{ }^{\circ}\end{array}$ & 17 & $\begin{array}{l}\text { MGT } \\
\text { N } 17\end{array}$ & $\begin{array}{l}\text { De Eerbaere Ivffr.Maria - Kieft Huysvrouw } \\
\text { Van } \mathbf{M}^{\mathrm{r}} \text {. - Sibrandvs Abbema Tweede - } \\
\text { Persoon Deeser Provintie - Banda } \\
\text { Overleden Den } 15 \text { - Feb'.A.1668 Ovdt } \\
\text { Synde - 24 Iaaren } 2 \text { Maend:7 Daegen. } \\
\text { (Wall, 1928: 48). }\end{array}$ \\
\hline & & & 18 & $\begin{array}{l}\text { MGT } \\
\text { N } 18\end{array}$ & $\begin{array}{l}\text { To The Memory - Of - Captain James } \\
\text { Logan, In The - Service Of The Hon "ble }\end{array}$ \\
\hline 11 & $\begin{array}{l}\text { MGT } \\
\text { N } 11\end{array}$ & $\begin{array}{l}\text { Hier Onder Legt - Begraven - Den Heer } \\
\text { Willem Adri - aan Van Weely, In Zyn - } \\
\text { Leven Coopman, En - Secunde deses } \\
\text { Gouver - nements, Gebooren Den - } \\
\text { 16:Iuny A A.1694.Overleden - Den 14:May } \\
\text { Anno 1727. } \\
\text { (Wall, 1928: 47). }\end{array}$ & & & $\begin{array}{l}\text { English - East India Compagny Who In } \\
\text { The - Prime Of Life Fell A Victim To } \\
\text { This - Vnsalvtary Climate On The } 5 \text { July - } \\
\text { Anno Domine } 1798 \text { His Zeal Con - } \\
\text { Dvct And Covrage Made Him A - Credit } \\
\text { To His Profession Whilst - His Liberal } \\
\text { Disposition Ingenuous - Manners And }\end{array}$ \\
\hline 12 & $\begin{array}{l}\text { MGT } \\
\text { N } 12\end{array}$ & $\begin{array}{l}\text { Hieronder Rust - Den WelEd:Mant:Heer - } \\
\text { Huybert:Van Dadelbeek - In Leeven } \\
\text { Captyn Ter - Zee By De OostInd:Comp : - } \\
\text { Overleden Den } 6 \text { May } 1793 . \\
\text { (Wall, 1928: 49). }\end{array}$ & & & $\begin{array}{l}\text { Unsullied Principles - Acquired Him Inj } \\
\text { Life The Love And - Esteem Of His } \\
\text { Friends - And - On His Death Their Sincere } \\
\text { Regret } \\
\text { (Wall, 1928: 55). }\end{array}$ \\
\hline
\end{tabular}




\begin{tabular}{|c|c|c|}
\hline 19 & $\begin{array}{l}\text { MGT } \\
\text { N } 19\end{array}$ & $\begin{array}{l}\text { Onder.Dese.Sark - Steen.Leit.Begraven. - } \\
\text { Den E.E.Achtb.Heere - } \\
\text { Salomon.Storm. - } \\
\text { Van.Middelb:In.Syn.Leven - } \\
\text { Gouvern:En.Direct:Deser. - } \\
\text { Provintie.Banda.Overleden. - Opp }{ }^{\mathrm{mo}} \text { Ianu: }^{\mathrm{ry}} \\
\mathrm{A}^{\mathrm{o}} \text { 1722.In.Den. - Ouderdom. } \\
\text { Van.54.Iaren. - }^{\text {Benevens.Zyn.E.Agtb }}{ }^{\mathrm{s}} \text { :Dochter. - } \\
\text { De.Iongeyuff: Constantsia.Storm - } \\
\text { Overleden:Den.26.Septermb }{ }^{\mathrm{r}} \text { Ao 1721. - } \\
\text { Oud.19.Iaren. En.3.Maenden. } \\
\text { (Wall, 1928: 41-42). }\end{array}$ \\
\hline 20 & $\begin{array}{l}\text { MGT } \\
\text { N } 20\end{array}$ & $\begin{array}{l}\text { In Hoc Tumulo Iacent - Bartholomeus Van } \\
\text { Walle - In Vita Mercator Inferior - Apud } \\
\text { Societatem Orient - Natus Medio Burgii In } \\
\text { Zeel }^{\text {d }} \text { - } 19 \text { Decemb Ao. } 1727 \text { Aetate tae: - } \\
\text { di isque sicuti apis Suprema - Subrosa, Die, } \\
\text { Extinctus.27 - Febr: Ao.1729.Minime } \\
\text { Aerumno - Sumerat:Quia virtetum.Jus: - } \\
\text { Titiamque Amabat - Et Suus Nepotulus - } \\
\text { Frederic:Jul:And'.Habich. - } \\
\text { Natus } 17 \text { April Et Morte Ab: - Parentibus } \\
\text { Suis, Atroce - Raptus.22 Jully Ao.1793. } \\
\text { (Wall, 1928: 55-56). }\end{array}$ \\
\hline 21 & $\begin{array}{l}\text { MGT } \\
\text { N } 21\end{array}$ & $\begin{array}{l}\text { Hier Rust Het Lichaem Van - Den } \\
\text { Eersamen Bandas Burger - Perquenier } \\
\text { Christoffel - Van Rensen. Overleden Alhier } \\
\text { - Ter Plaetse Op Den } 3 \text { February - } \\
1735 \text { In Den Ouderdom Van } 66 \text { - Jaren } 1 \\
\text { Maend En } 27 \text { Dagen. }\end{array}$ \\
\hline
\end{tabular}

22 MGT Hier Onder Legt Het Lyk Van D’Heer -

N 22 Abraham Frans De Walsche In Zyn

Leven - Burger En Percq ${ }^{\mathrm{r}}$ :Tot Spantje By

Obyt Den - 22 February Ao. 1740:Oud

Zynde 39 Jaa - Ren 9 Maanden En

17:Dagen ; - Mitsgad ${ }^{\mathrm{s}}$. -

Mejuff $^{\mathrm{w}}$.Hillegonda Jurriaansz. - In Haar

Leven Laast:Wed ${ }^{\mathrm{e}}$.Wylen - Den

Ondercoopman :En Wayers -

Hooft D'Heer Hendrik Brinkman - Obyt

Den 2:April Ao. 1741 Oud 62 - Jaren.3

Maanden.En 20:Dagen

(Wall, 1928: 52).

\begin{tabular}{|c|c|c|}
\hline 23 & $\begin{array}{l}\text { MGT } \\
\text { N } 23\end{array}$ & - \\
\hline 24 & $\begin{array}{l}\text { MGT } \\
\text { N } 24\end{array}$ & - \\
\hline 25 & $\begin{array}{l}\text { MGT } \\
\text { N } 25\end{array}$ & $\begin{array}{l}\text { HIER ONDER RUAT HET - LICHAEM } \\
\text { VAN DEN .. HER LUCAS - BEIRNIN. IN } \\
\text { ZYN LEVEN - COOPMAN IN [...........] - } \\
\text { TEN [.....] AY OBIT DEN } 25 \text { - } \\
\text { IANUARY A } 1723 \text { IN DEN OUDER - } \\
\text { DOM VAN } 35 \text { JAREN } 21 \text { MAANDEN - } \\
\text { EN } 27 \text { DAGEN }\end{array}$ \\
\hline 26 & $\begin{array}{l}\text { MGT } \\
\text { N } 26\end{array}$ & $\begin{array}{l}\text { HIER ONDER BRIST, NAVEEL - } \\
\text { DROEF HEYT [....] GESTA AN TE - } \\
\text { HEBBEN [........] WE AGETHA - } \\
\text { SUSAN [.......] IN MAAR ED[..] - } \\
\text { LEEVEN [......]OUW VAN DEN - } \\
\text { WELEDELEN [......]BAAR EN HEE - RE } \\
\text { RENICUS [...]RSMA GOUVER - } \\
\text { NEUR EN DIRECTEUR DESER PRO - } \\
\text { VINTIE BANDA OBT ADYJ } 9 \text { XBER - } \\
\text { A }^{\mathrm{O}} 1753 \text { OUD } 42 \text { IAREN } 4 \text { MAANDEN - } \\
\text { EN } 8 \text { DAGEN }\end{array}$ \\
\hline 27 & $\begin{array}{l}\text { MGT } \\
\text { N } 27\end{array}$ & $\begin{array}{l}\text { Hieronder Legt - Begraven - Den } \\
\text { WelEdelen Agt. - Baren Heer Johannes Ha }\end{array}$ \\
\hline
\end{tabular}

- Geman In Syne.Eds:Leven, -

Oppercoopman En Ge - Zaghebber Deeser

Pro: - Vintie Banda En Resorte - Van

Dien.Geboren Tot Amster -

Dam Den 1:Mey 1745 En Overleden - Den

13 January 1794 Oud Zynde -

48 Jaren, 8 Maanden en 5 Dage

(Wall, 1928: 47).

Sumber: Diolah dari Wall, 1928 dan Dok. Balai Arkeologi Maluku, 2013.

Angka tahun yang tertera pada batu nisan berdasarkan posisi keletakannya di lantai bangunan gereja tampaknya tersusun dengan pola yang acak. Dengan kata lain bahwa urutan tahun meninggalnya orang yang dimakamkan tidak tersusun secara kronologis mulai dari tahun yang paling tua ke tahun yang lebih muda atau sebaliknya. Hal ini tampak pada konfigurasi susunan batu nisan. Angka tahun paling tua berdasarkan inskripsi batu nisan yang menunjukkan tahun 1668 berada di tengah-tengah ruang jemaat. Sementara batu nisan dengan angka tahun paling muda yang menunjukkan tahun 1800 berada di sisi kiri bagian teras depan. Selain itu, batu nisan dengan angka tahun paling muda yang terdapat di dalam bangunan gereja menunjukkan angka tahun 1798. Posisi keletakan batu nisan dengan angka tahun paling tua terdapat di tengahtengah ruang jemaat, sementara batu nisan dengan angka tahun paling muda terdapat di bagian teras depan yaitu sisi kiri teras.

Jika dirinci lebih detail lagi, angka tahun paling tua pada inskripsi yang ditulis dalam bahasa Latin menunjukkan tahun 1793 dan angka tahun paling muda menunjukkan tahun 1796. Angka tahun paling tua pada inskripsi dalam bahasa Inggris menunjukkan tahun 1798, dan paling muda tahun 1800. Sementara itu, angka tahun paling tua pada inskripsi bahasa Belanda menunjukkan tahun 1668 dan paling muda menunjukkan tahun 1793 .

\section{Aspek Sosio-Historis pada Inskripsi Batu Nisan}

Dalam kehidupan komunitas Kristen Kolonial, prosesi kematian merupakan upacara daur hidup yang ketiga atau 
terakhir selain upacara kelahiran dan pernikahan. Upacara kematian pada umumnya diselenggarakan dengan mewah dan menelan biaya sangat besar terutama untuk pejabat VOC atau Pemerintah Hindia Belanda. Prosesi ini memerlukan pengerahan banyak tenaga dan pemikiran berbagai pihak. Tidak hanya itu, batu nisan dibuat sangat indah merupakan salah satu penghormatan terhadap orang yang dimakamkan, sehingga batu nisan menjadi simbol kemewahan. Pada awalnya, batu nisan banyak didatangkan dari Koromandel (India), dibuat dari jenis arduin biru atau jenis batu yang sangat keras (Soekiman, 2011: 90). Dengan demikian, sebuah batu nisan dianggap simbol kemewahan karena terbuat dari bahan berkualitas terbaik serta didatangkan dari tempat yang jauh dengan biaya yang mahal. Selain itu, simbol kemewahan sebuah batu nisan tampak pada kelengkapan ragam hias di antaranya; inskripsi, iluminasi dan lambang heraldik. Keseluruhan ragam hias ini dibuat dengan teknik pahat yang dikerjakan dengan tangan sehingga memiliki kualitas ragam hias yang tinggi. Hal ini pula yang menjadikan batu nisan berkualitas tinggi hanya digunakan bagi orang-orang yang juga memiliki status sosial tinggi.

Dalam inskripsi batu nisan terdapat keterangan yang memuat tentang nama orang yang dimakamkan, jabatan yang pernah disandang, tempat lahir, tanggal lahir, tempat meninggal, dan tanggal meninggal. Salah satu batu nisan (MGTN 14) tidak memuat tentang keterangan tentang siapa yang dimakamkan, namun kemungkinan memuat sebuah puisi atau ungkapan tentang sebuah peristiwa. Batu nisan ini kemungkinan berhubungan dengan informasi bahwa gereja ini dibangun di atas makam tentara-tentara Belanda yang gugur pada saat penaklukkan Banda di awal abad ke-17. Berdasarkan data inskripsi pada batu nisan dapat diungkap beberapa hal terkait dengan aspek sosio-historis masyarakat Eropa di Kepulauan Banda.
Keseluruhan jumlah batu nisan adalah 27 buah dan berdasarkan data inskripsi diketahui tidak hanya 1 nama orang dalam 1 batu nisan, tetapi terdapat 2 nama bahkan lebih. Hal itu karena sistem pemakaman masyarakat Eropa yang menganut agama Kristen mengenal sistem pemakaman di mana satu liang lahat dapat diisi lebih dari satu jenasah. Keterangan pada batu nisan menjelaskan tentang riwayat hidup orang yang dimakamkan maka diperoleh beberapa pembagian tentang status sosialnya. Berdasarkan data ini, status sosial paling tinggi yang dapat diidentifikasi adalah gubernur, dan diikuti status sosial lain yaitu; keluarga gubernur, direktur, anggota Dewan Propinsi, pendeta/anggota Dewan Gereja, pejabat militer, pejabat perdagangan, Burger, dan Perkenier. Dengan demikian, status sosial tersebut dapat dikelompokkan atas 6 kelompok yaitu, Kelompok 1 (gubernur); Kelompok 2 (keluarga gubernur); Kelompok 3 (anggota Dewan Propinsi, Pejabat Perdagangan dan keluarga); Kelompok 4 (anggota Dewan Gereja/ Pendeta); Kelompok 5 (militer dan keluarga); Kelompok 6 (Perkenier, Burger dan keluarga). Lebih lengkap tentang pengelompokan status sosial berdasarkan data inskripsi pada batu nisan dapat dilihat pada tabel berikut.

Tabel 3. Kelompok 1: Gubernur

\begin{tabular}{|c|c|c|c|c|}
\hline No & Kode & Nama & $\begin{array}{l}\text { Status } \\
\text { Sosial }\end{array}$ & Usia \\
\hline 1. & $\begin{array}{c}\text { MGTN } \\
3\end{array}$ & $\begin{array}{l}\text { Willem } \\
\text { Maetsvycker }\end{array}$ & Gubernur & $\begin{array}{l}\text { Meninggal } \\
14 \text { Januari } \\
1675\end{array}$ \\
\hline 2. & $\begin{array}{c}\text { MGTN } \\
6\end{array}$ & $\begin{array}{l}\text { Aldert } \\
\text { Aldertsz }\end{array}$ & $\begin{array}{l}\text { Gubernur } \\
\text { dan } \\
\text { Direktur } \\
\text { Banda }\end{array}$ & $\begin{array}{l}\text { Lahir } 17 \\
\text { Oktober } \\
1685 \\
\text { Meninggal } \\
17 \text { Agustus } \\
1727 \text { pada } \\
\text { usia } 41 \\
\text { tahun } 9 \\
\text { bulan } 3 \text { hari }\end{array}$ \\
\hline 3. & & - & Gubernur & $\begin{array}{l}\text { Meninggal } \\
5 \text { Maret } \\
1732 \text { pada } \\
\text { usia } 36 \\
\text { tahun } 1 \\
\text { bulan } 10 \\
\text { hari }\end{array}$ \\
\hline 4. & MGTN & Cornelis & Gubernur & Meninggal \\
\hline
\end{tabular}




\begin{tabular}{|c|c|c|c|c|c|c|c|c|c|}
\hline & 8 & Stull & $\begin{array}{l}\text { dan } \\
\text { Direktur } \\
\text { Propinsi } \\
\text { Banda }\end{array}$ & $\begin{array}{l}\text { pada } 6 \\
\text { Oktober } \\
1704 \text { pada } \\
\text { usia } 55 \\
\text { tahun } 9\end{array}$ & 3. & & $\begin{array}{l}\text { Anna } \\
\text { Rensina }\end{array}$ & $\begin{array}{l}\text { Anak dari } \\
\text { Aldert } \\
\text { Aldertsz }\end{array}$ & $\begin{array}{l}\text { Lahir } 6 \\
\text { Maret } \\
1718 \\
\text { Meninggal } \\
\text { 16 Maret }\end{array}$ \\
\hline & & & & bulan 2 hari & \multirow[t]{6}{*}{4.} & & Mathys & \multirow{6}{*}{$\begin{array}{l}\text { Anak dari } \\
\text { Aldert } \\
\text { Aldertsz }\end{array}$} & Lahir \\
\hline \multirow[t]{7}{*}{5.} & MGTN & Nicalaus & Gubernur & Meninggal & & & Andris & & Oktober \\
\hline & 9 & Nicolai & & 28 Maret & & & & & 1721 \\
\hline & & & Direktur & 1740 pada & & & & & Meninggal \\
\hline & & & Propinsi & usia 44 & & & & & 7 Februari \\
\hline & & & Banda & tahun 9 & & & & & 1722 \\
\hline & & & & bulan 24 & \multirow[t]{4}{*}{5.} & MGTN & Cornelia & Anak dari & Meninggal \\
\hline & & & & hari & & 8 & Jacoba Stull & Cornelis & 19 Oktober \\
\hline \multirow[t]{4}{*}{6.} & MGTN & Salomon & Gubernur & Meninggal & & & & Stull & 1701 pada \\
\hline & 19 & $\begin{array}{l}\text { Storm van } \\
\text { Middelburg }\end{array}$ & $\begin{array}{l}\text { dan } \\
\text { Direktur }\end{array}$ & $\begin{array}{l}\text { Januari } \\
1722 \text { pada }\end{array}$ & & & & (Gubernur) & $\begin{array}{l}\text { usia } 6 \\
\text { bulan }\end{array}$ \\
\hline & & & Propinsi & usia 54 & \multirow{6}{*}{6.} & \multirow{6}{*}{$\begin{array}{c}\text { MGTN } \\
19\end{array}$} & \multirow{6}{*}{$\begin{array}{l}\text { Constantsia } \\
\text { Storm }\end{array}$} & \multirow{6}{*}{$\begin{array}{l}\text { Putri } \\
\text { Salomon } \\
\text { Storm } \\
\text { (Gubernur } \\
\text { dan } \\
\text { Direktur } \\
\text { Banda) }\end{array}$} & \multirow{6}{*}{$\begin{array}{l}\text { Meninggal } \\
\text { pada } 26 \\
\text { September } \\
1721 \text { pada } \\
\text { usia } 19 \\
\text { tahun } 3 \\
\text { bulan }\end{array}$} \\
\hline & & & Banda & tahun & & & & & \\
\hline \multirow{11}{*}{\multicolumn{5}{|c|}{$\begin{array}{l}\text { Sumber: Hasil analisis pada inskripsi batu } \\
\text { nisan. } \\
\text { Pada tabel Kelompok 1, jabatan } \\
\text { gubernur dan direktur Propinsi Banda } \\
\text { merupakan jabatan tertinggi dalam struktur } \\
\text { pemerintahan VOC. Pada saat itu, Kepu- } \\
\text { lauan Banda merupakan wilayah setingkat } \\
\text { propinsi setelah VOC memutuskan untuk } \\
\text { mendirikan sebuah kota baru sebagai pusat }\end{array}$}} & & & & & \\
\hline & & & & & & & & & \\
\hline & & & & & & & & & \\
\hline & & & & & & & & & \\
\hline & & & & & 7. & MGTN & Agatha & Istri & Meninggal \\
\hline & & & & & & 26 & Susanna & Gubernur & pada 9 \\
\hline & & & & & & & & dan & Oktober \\
\hline & & & & & & & & Direktur & 1753 pada \\
\hline & & & & & & & & Banda & $\begin{array}{l}\text { usia } 42 \\
\text { tahun } 4\end{array}$ \\
\hline & & & & & & & & & bulan 4 \\
\hline & & & & & & & & & hari \\
\hline
\end{tabular}
pemerintahan dengan nama Batavia pada 28 Mei 1619, sebelumnya sejak tahun 1610-1619 pusat pemerintahan VOC berada di Maluku (Ricklefs, 2010: 54). Pada inskripsi masing-masing tokoh yang dimakamkan tampak jelas penyebutan bagi mereka dengan jabatan tinggi seperti $D e$ Heer Gouvern ${ }^{r}$ (Willem Maetsvycker), sementara penyebutan jabatan bagi tokoh yang lain disebutkan setelah penyebutan nama seperti (Aldert Aldertsz) In Syn E.E.s.Lev ${ }^{n s}$ Gouvern $^{r}$ En Direct ${ }^{r}$ Des. ${ }^{r}$ Eyland Banda; (Nicalaus Nicolai) In Leven Gouverneur En Directeur Op Banda.

Tabel 4. Kelompok 2: Keluarga Gubernur

\begin{tabular}{|c|c|c|c|c|}
\hline No & Kode & Nama & $\begin{array}{l}\text { Status } \\
\text { Sosial }\end{array}$ & Usia \\
\hline 1. & $\begin{array}{c}\text { MGTN } \\
4\end{array}$ & $\begin{array}{l}\text { Engeltie } \\
\text { Gramsbergh }\end{array}$ & $\begin{array}{l}\text { Istri dari } \\
\text { Theodorus } \\
\text { De Haeze } \\
\text { (Gubernur } \\
\text { dan } \\
\text { Direktur } \\
\text { Banda) }\end{array}$ & $\begin{array}{l}\text { Meninggal } \\
31 \text { Oktober } \\
1708 \text { pada } \\
\text { usia } 45 \\
\text { tahun } 10 \\
\text { bulan } 21 \\
\text { hari }\end{array}$ \\
\hline 2. & $\begin{array}{c}\text { MGTN } \\
6\end{array}$ & Andris & $\begin{array}{l}\text { Anak dari } \\
\text { Aldert } \\
\text { Aldertsz }\end{array}$ & $\begin{array}{l}\text { Lahir } 26 \\
\text { Februari } \\
1714, \\
\text { Meninggal } \\
2 \text { Juni }\end{array}$ \\
\hline
\end{tabular}

Sumber: Hasil analisis pada inskripsi batu nisan.

Pada tabel Kelompok 2 diperoleh informasi bahwa orang yang dimakamkan adalah anak dari seorang gubernur yang dimakamkan bersama dengan ayahnya dalam satu liang lahat (sebagaimana inskripsi pada batu nisan MGTN 6, MGTN 8,dan MGTN 19). Inskripsi pada batu nisan MGTN 6 diketahui ada tiga orang anak (dari Aldert Aldertsz) yang bahkan masih berusia bayi, yaitu Andris (usia 4 bulan), Anna Rensina (usia 10 hari), Mathys Andris (usia 4 bulan). Ketiga anak ini meninggal mendahului sang ayah, demikian pula inskripsi pada batu nisan MGTN 8 yaitu Cornelia Jacoba Stull (3 tahun sebelum ayahnya meninggal pada 1704) dan Constantsia Storm (1 tahun sebelum ayahnya meninggal pada 1722). Sementara itu, informasi lain diperoleh dari batu nisan MGTN 4, Engeltie Gramsbergh merupakan istri dari seorang gubernur yang mendapat sebutan Mejuffrouw. Dan keterangan tentang nama suami dan jabatan suaminya disebutkan setelah menuliskan nama orang yang meninggal. Demikian halnya Agatha 
Susanna yang juga istri seorang gubernur, meski dengan sebutan berbeda yaitu mevrouwe.

Tabel 5. Kelompok 3: Anggota Dewan Propinsi, Pejabat Perdagangan dan Keluarga

\begin{tabular}{|c|c|c|c|c|}
\hline No & Kode & Nama & $\begin{array}{l}\text { Status } \\
\text { Sosial }\end{array}$ & Usia \\
\hline 1. & $\begin{array}{c}\text { MGTN } \\
5\end{array}$ & $\begin{array}{l}\text { Rebecca } \\
\text { Dorothea }\end{array}$ & $\begin{array}{l}\text { Istri } \\
\text { Jacques } \\
\text { Barriel } \\
\text { (Saudagar } \\
\text { Kepala dan } \\
\text { Anggota } \\
\text { Dewan } \\
\text { Propinsi) }\end{array}$ & $\begin{array}{l}\text { Meninggal } \\
31 \\
\text { Desember } \\
1748 \text { pada } \\
\text { usia 26 } \\
\text { tahun } 11 \\
\text { hari }\end{array}$ \\
\hline 2. & $\begin{array}{c}\text { MGTN } \\
11\end{array}$ & $\begin{array}{l}\text { Willem } \\
\text { Adriaan } \\
\text { van Weely }\end{array}$ & $\begin{array}{l}\text { Saudagar } \\
\text { dan } \\
\text { Anggota } \\
\text { Dewan } \\
\text { Propinsi }\end{array}$ & $\begin{array}{l}\text { Lahir } 16 \\
\text { Juni 1694, } \\
\text { Meninggal } \\
14 \text { Mei } \\
1727\end{array}$ \\
\hline 3. & $\begin{array}{c}\text { MGTN } \\
17\end{array}$ & $\begin{array}{l}\text { Maria } \\
\text { Kieft }\end{array}$ & $\begin{array}{l}\text { Istri } \\
\text { Sibrandvs } \\
\text { Abbema } \\
\text { (Anggota } \\
\text { Dewan } \\
\text { Propinsi) }\end{array}$ & $\begin{array}{l}\text { Meninggal } \\
15 \text { Februari } \\
1668 \text { pada } \\
\text { usia } 24 \\
\text { tahun } 2 \\
\text { bulan } 7 \text { hari }\end{array}$ \\
\hline 4. & $\begin{array}{c}\text { MGTN } \\
22\end{array}$ & $\begin{array}{l}\text { Hillegonda } \\
\text { Jurriaansz }\end{array}$ & $\begin{array}{l}\text { Istri } \\
\text { Hendrik } \\
\text { Brinkman } \\
\text { (Wakil } \\
\text { Saudagar } \\
\text { dan Kepala } \\
\text { Pemerin- } \\
\text { tahan di } \\
\text { Wayer) }\end{array}$ & $\begin{array}{l}\text { Meninggal } 2 \\
\text { April } 1741 \\
\text { pada usia } 62 \\
\text { tahun } 3 \\
\text { bulan } 20 \\
\text { hari }\end{array}$ \\
\hline 5. & $\begin{array}{c}\text { MGTN } \\
25\end{array}$ & $\begin{array}{l}\text { Lucas } \\
\text { Beirnin }\end{array}$ & $\begin{array}{l}\text { Saudagar } \\
\text { di Ay }\end{array}$ & $\begin{array}{l}\text { Meninggal } \\
25 \text { Januari } \\
1723 \text { pada } \\
\text { usia } 35 \\
\text { tahun } 21 \\
\text { bulan } 27 \\
\text { hari }\end{array}$ \\
\hline 6. & $\begin{array}{c}\text { MGTN } \\
27\end{array}$ & $\begin{array}{l}\text { Johannes } \\
\text { Hageman }\end{array}$ & $\begin{array}{l}\text { Kepala } \\
\text { Saudagar } \\
\text { dan } \\
\text { Anggota } \\
\text { Dewan } \\
\text { Propinsi }\end{array}$ & $\begin{array}{l}\text { Lahir di } \\
\text { Amsterdam } \\
1 \text { Mei } 1745 \\
\text { Meninggal } \\
13 \text { Januari } \\
1794 \text { pada } \\
\text { usia } 48 \\
\text { tahun } 8 \\
\text { bulan } 5 \text { hari }\end{array}$ \\
\hline
\end{tabular}

Sumber: Hasil analisis pada inskripsi batu nisan.

Berdasarkan pada tabel Kelompok 3, diperoleh informasi tentang struktur jabatan dalam pemerintahan VOC di Banda, baik yang berhubungan dengan bidang pemerintahan maupun perdagang- 4 . an. Dalam bidang pemerintahan terdapat jabatan Dewan Propinsi yang disebut Secunde Deeses Gouvernement (Inskripsi batu nisan MGTN 5 dan MGTN 11), Tweede Persoon Deeser Provintie Banda (MGTN 17), dan Gezaghebber Deeser Provintie Banda (MGTN 27). Sementara itu, jabatan dalam bidang perdagangan disebut Oppercoopman (MGTN 5 dan MGTN 27), Coopman (MGTN 11), dan Ondercoopman (MGTN 22 dan MGTN 25).

Tabel 6. Kelompok 4: Anggota Dewan Propinsi, Pejabat Perdagangan dan Keluarga

\begin{tabular}{|c|c|c|c|c|}
\hline No & Kode & Nama & $\begin{array}{l}\text { Status } \\
\text { Sosial }\end{array}$ & Usia \\
\hline 1. & $\begin{array}{c}\text { MGTN } \\
10\end{array}$ & $\begin{array}{l}\text { Samuel } \\
\text { Maesius }\end{array}$ & $\begin{array}{l}\text { Anggota } \\
\text { Jemaat } \\
\text { Gereja }\end{array}$ & $\begin{array}{l}\text { Meninggal } 19 \\
\text { Mei } 1740 \text { pada } \\
\text { usia } 44 \text { tahun } 9 \\
\text { bulan } 24 \text { hari }\end{array}$ \\
\hline 2. & & $\begin{array}{l}\text { Johan } \\
\text { Philips } \\
\text { Maesius }\end{array}$ & $\begin{array}{l}\text { Asisten } \\
\text { Anggota } \\
\text { Jemaat }\end{array}$ & $\begin{array}{l}\text { Meninggal } 17 \\
\text { Februari } 1734\end{array}$ \\
\hline
\end{tabular}

Pada tabel Kelompok 4 diperoleh informasi yang menjelaskan tentang kedudukan pejabat keagamaan. Hal itu diperoleh berdasarkan inskripsi pada batu nisan dengan Kode MGTN 10 yang menyebutkan De Christelyke Gemeente Alhier Op Neira (Samuel Maesius) dan Geweest Adsistent (Johan Philips Maesius).

Tabel 7. Kelompok 5: Anggota Dewan Propinsi, Pejabat Perdagangan dan Keluarga

\begin{tabular}{|c|c|c|c|c|}
\hline No & Kode & Nama & $\begin{array}{l}\text { Status } \\
\text { Sosial }\end{array}$ & Usia \\
\hline 1. & $\begin{array}{c}\text { MGTN } \\
1\end{array}$ & $\begin{array}{l}\text { Mr. John Mc. } \\
\text { Leod }\end{array}$ & $\begin{array}{l}\text { Angkatan } \\
\text { Laut Inggris }\end{array}$ & $\begin{array}{l}\text { Meninggal } \\
14 \text { April } \\
1800 \text { pada } \\
\text { usia } 21 \\
\text { tahun }\end{array}$ \\
\hline 2. & $\begin{array}{c}\text { MGTN } \\
2\end{array}$ & $\begin{array}{l}\text { Alexander La } \\
\text { Mote }\end{array}$ & $\begin{array}{l}\text { Militer } \\
\text { Inggris }\end{array}$ & $\begin{array}{l}\text { Lahir } \\
\text { Februari } \\
1770, \\
\text { Meninggal } \\
1796\end{array}$ \\
\hline 3. & $\begin{array}{c}\text { MGTN } \\
7\end{array}$ & $\begin{array}{l}\text { Maria } \\
\text { Melgertssen } \\
\text { van Haarlem }\end{array}$ & $\begin{array}{l}\text { Istri Jan } \\
\text { Jacobse } \\
\text { Heysselberg } \\
\text { (Kapten } \\
\text { Militer) }\end{array}$ & $\begin{array}{l}\text { Lahir } 7 \text { Mei } \\
1624 \text { dan } \\
\text { Meninggal } \\
\text { 19 Juni } \\
1684\end{array}$ \\
\hline 4. & & $\begin{array}{l}\text { Iacob } \\
\text { Heysselbergh }\end{array}$ & $\begin{array}{l}\text { Anggota } \\
\text { Militer } \\
\text { VOC }\end{array}$ & $\begin{array}{l}\text { Meninggal } \\
21 \text { Oktober } \\
1683 \text { pada } \\
\text { usia } 23 \\
\text { tahun } 3 \\
\text { bulan } 9 \text { hari }\end{array}$ \\
\hline
\end{tabular}




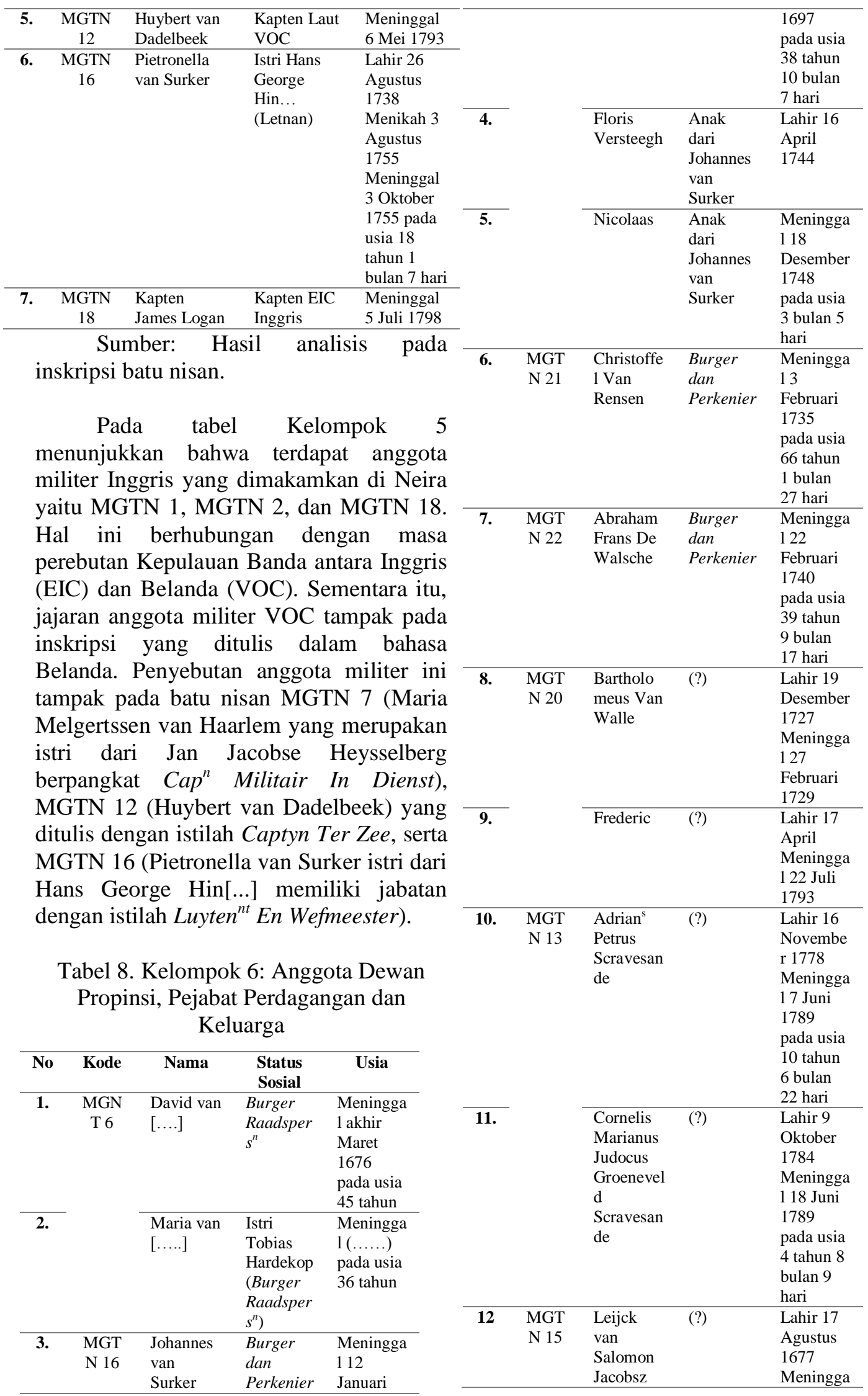


15 Septembe

r 1740

pada usia

73 tahun

18 hari

Sumber: Hasil analisis pada inskripsi batu nisan.

Pada tabel Kelompok 6 merupakan informasi tentang generasi awal atau tokoh-tokoh pendiri perk yang ada di Kepulauan Banda. Selain itu, inskripsi pada batu nisan MGTN 6 diperoleh informasi sebuah jabatan yang disebut Burger Raadspers ${ }^{n}$. Demikian halnya, status sosial pada batu nisan MGTN 20 dengan inskripsi bahasa Latin yang menggunakan istilah mercator atau pedagang.

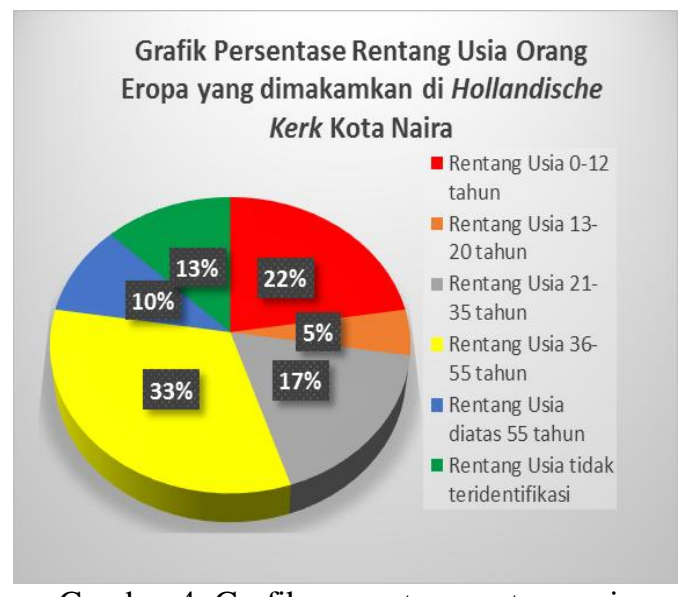

Gambar 4. Grafik persentase rentang usia jenazah yang dimakamkan

Sumber: Diolah berdasarkan data inskripsi pada batu nisan.

Berdasarkan data inskripsi, sebagian besar yang dimakamkan adalah keluarga, baik istri maupun anak-anak para pejabat VOC. Dari 40 nama yang berhasil diidentifikasi, 9 (sembilan) atau $22 \%$ di antaranya adalah anak-anak di bawah umur 10 tahun (lebih lengkap tentang persentase rentang usia orang-orang yang dimakamkan di Hollandische Kerk dapat dilihat pada grafik 1).

Grafik ini sekaligus menunjukkan bahwa sebagian besar dari orang Eropa yang dimakamkan adalah mereka yang masih berusia di bawah usia 55 tahun yang angkanya mencapai $77 \%$. Hal ini memunculkan interpretasi bahwa orang-orang Eropa yang meninggal dan dimakamkan di Banda Neira adalah mereka yang dapat dikategorikan masih dalam usia produktif. Di sisi lain, berdasarkan angka tahun pada batu nisan memperlihatkan bahwa sebagian besar orang yang dimakamkan menunjukkan tahun meninggal adalah pada periode 1701-1750. Persentase pada periode ini menunjukkan angka $55 \%$ jika dibandingkan pada periode baik sebelum maupun setelahnya. Hal ini tentu menegaskan kejayaan perdagangan pala yang mendatangkan keuntungan besar membuat orang-orang Eropa di Banda berlombalomba untuk menunjukkan status sosial mereka dengan memesan batu nisan yang pada masa itu merupakan barang yang mahal. Terlebih, di Kepulauan Banda yang jauh dari pusat pemerintahan yang ada di Batavia ketika itu. Hal ini selaras dengan periode kejayaan komoditi pala pada masa VOC (dan Hindia Belanda) yang menyebutkan bahwa era keemasan para perkenier di Kepulauan Banda berlangsung dalam dua periode yaitu 1700-1750 dan 1870-1890 (Suratminto, 2011).

\section{PENUTUP}

Tipologi yang tampak pada batu nisan yang ada di Hollandische Kerk umumnya berbentuk persegi panjang dengan variasi ragam hias. Teknologi pembuatan batu nisan menggunakan teknik pangkas dan teknik pahat, teknik pangkas digunakan pada saat pembentukan awal dan teknik pahat digunakan pada saat pembuatan ragam hias. Ragam hias yang tampak pada batu nisan di antaranya; variasi antara inskripsi, lambang heraldik, dan iluminasi. Keseluruhan batu nisan yang tampak di lantai bangunan berbentuk plat dan ditempatkan pada posisi horizontal di lantai bangunan. Sementara itu, berdasarkan pada inskripsi batu nisan, diketahui bahwa orang-orang yang dimakamkan adalah keluarga yang memiliki status sosial tinggi di antaranya 
para pejabat pemerintahan, pejabat militer, pejabat perdagangan, pejabat keagamaan, dan para perkenier.

Dengan demikian, kehidupan sosial masyarakat Eropa di Kepulauan Banda pada masa itu memiliki keinginan yang kuat untuk menjalani kehidupan sesuai dengan gaya hidup masyarakat di Eropa pada umumnya. Di mana simbol-simbol kemewahan tidak hanya ketika seseorang menjalani kehidupan sehari-hari tetapi juga ketika seseorang telah meninggal. Hal ini tampak jelas pada batu nisan yang terdapat di lantai bangunan Hollandische Kerk.

Sementara itu, inskripsi pada batu nisan memberi informasi yang jelas rentang usia atau masa hidup orang-orang yang dimakamkan. Diperoleh informasi bahwa rentang usia paling dominan adalah usia yang dapat digolongkan sebagai usia produktif yaitu usia 36-55 tahun. Hal ini menunjukkan bahwa kehidupan orangorang Eropa di Kepulauan Banda masih pada tahap adaptasi dengan lingkungan baru, di mana saat itu periode abad ke-17 hingga abad ke-18 merupakan periode awal kehadiran bangsa Eropa di Kepulauan Banda.

Inskripsi pada batu nisan di Hollandische Kerk juga menampilkan angka tahun tertua yaitu tahun 1668 dan angka tahun paling muda yaitu tahun 1800 . Sementara itu, angka tahun yang dominan berkisar pada 1700-1750. Terdapat dugaan bahwa batu nisan yang ada di lantai bangunan Hollandische Kerk merupakan relokasi atau dipindahkan dari tempat semula. Hal ini diketahui setelah membandingkan sejarah pembangunan Hollandische Kerk yang dibangun sekitar tahun 1870-an dan angka tahun yang terdapat pada inskripsi batu nisan yang sebagian besar menunjukkan angka tahun sebelum tahun 1801. Demikian halnya jika mengamati penempatan batu nisan yang disusun secara acak -berdasarkan angka tahun- pada lantai bangunan gereja.

Demikian, kajian atas aspek tipologi dan data inskripsi pada batu nisan yang ada di Kepulauan Banda. Kajian ini merupakan studi awal untuk membuka ruang kajian lebih mendalam terkait dengan berbagai aspek yang dapat diungkapkan dari batu nisan yang ada di lokasi penelitian. Kajiankajian lanjutan setidaknya menjadi penting termasuk dalam aspek ungkapan-ungkapan yang terdapat pada inskripsi, serta makna atas hubungan antara inskripsi dan lambang heraldik atau simbol yang terdapat pada batu nisan. Aspek lain adalah aspek tata bahasa - Belanda yang digunakan dalam inskripsi, sebagaimana diketahui bahwa bahasa yang digunakan pada inskripsi batu nisan tersebut adalah bahasa Belanda kuno yang berasal dari abad ke-17/18. Dengan demikian, penting untuk melestarikan tinggalan arkeologi yang ada di wilayah Kepulauan Banda sebagai upaya untuk mengungkap berbagai hal terkait sejarah budaya di wilayah tersebut.

\section{DAFTAR SUMBER}

\section{Laporan Penelitian dan Skripsi}

Handayani, Rosaeny. 2009.

Bentuk-Bentuk Nisan di Museum Taman Prasasti Jakarta. Skripsi Program Studi Arkeologi, Fakultas Ilmu Pengetahuan Budaya. Depok: Universitas Indonesia.

Inagurasi, Libra Hari. 2014.

"Pola Pemukiman Kawasan Perkebunan Karet Masa Hindia Belanda di Bogor" dalam Amerta: Jurnal Penelitian dan Pengembangan Arkeologi Vol. 32 No. 1 Juni 2014. Hal. 49-62.

Koestoro, Lucas Partanda et al. 2013.

"Medan, Kota di Pesisir Timur Sumatera dan Peninggalan Tuanya" dalam Berita Penelitian Arkeologi No. 28. Medan: Balai Arkeologi Medan.

Tim Penelitian. 2009.

Persepsi Masyarakat terhadap Pengelolaan Benda Cagar Budaya di Banda Neira. Laporan Penelitian. Ambon: Balai Arkeologi Ambon.

Tim Penelitian. 2010.

Kepulauan Banda, Maluku Tengah, Pusat Perdagangan Pala Abad ke-16- 
19. Laporan Penelitian. Jakarta: Pusat Penelitian dan Pengembangan Arkeologi.

Tim Penelitian. 2012.

Ekskavasi Situs Perk Mangkubatu, Kepulauan Banda, Maluku Tengah. Laporan Penelitian. Jakarta: Pusat Arkeologi Nasional.

Tim Penelitian. 2013.

Survey Eksploratif Makam Eropa di Kepulauan Banda, Maluku Tengah. Laporan Penelitian. Ambon: Balai Arkeologi Ambon.

\section{Buku}

Abrianto, Octaviadi. 2010.

"Kota Cirebon: Potensi dan Permasalahannya" dalam Dari Masa Lalu ke Masa Kini: Kajian Budaya Materi, Tradisi, dan Pariwisata. Hal. 151-163. (eds. Wanny Rahardjo Wahyudi). Bandung: Balai Arkeologi Bandung.

Alwi, Des. 2005.

Sejarah Maluku, Banda Neira, Ternate, Tidore dan Ambon. Jakarta: Dian Rakyat Indonesia bekerjasama dengan Yayasan Warisan dan Budaya Banda.

Anonim. 2008

Metode Penelitian Arkeologi. Jakarta: Pusat Penelitian dan Pengembangan Arkeologi Nasional.

Deetz, James. 1976.

Invitation to Archaeology. London: Cambridge University Press.

Hanna, Willard.A. 1983.

Kepulauan Banda: Kolonialisme dan Akibatnya di Kepulauan Pala. Jakarta: Yayasan Obor Indonesia - Gramedia.

Ricklefs, M.C. 2010

Sejarah Indonesia Modern: 1200-2008. Cetakan Ketiga. Jakarta: Serambi.

Soekiman, Djoko. 2011.

Kebudayaan Indis: Dari Zaman Kompeni sampai Revolusi. Depok: Komunitas Bambu.

Suratminto, Lilie. 2008.

Makna Sosio-Historis Batu Nisan VOC di Batavia. Jakarta: Wedatama Wedya Sastra.
Wall, Victor Ido van de. 1928.

de Nederlandsche Oudheden in de Molukken. Gravenhage: Martinus Hijhoff.

Turner, Jack. 2011.

Sejarah Rempah: Dari Erotisme sampai Imprealisme. Jakarta: Komunitas Bambu.

\section{Internet}

Suratminto, L. 2011.

"Runtuhnya Kejayaan Masyarakat Perkenier di Kepulauan Banda pada Masa Kolonial Hindia-Belanda", diakses dari: http://fis.um.ac.id,, diakses tanggal 11 Juni 2016. 